\title{
Gonzalo Munévar
}

\section{Damásio, jaźń i świadomość *}

\section{Wprowadzenie}

António Damásio ma tyle ważnych zasług dla neuronauki, że podjęciu jakiejkolwiek krytyki jego poglądów musi towarzyszyć znaczna doza niepokoju. Wydaje mi się jednak, że zakładane przezeń bliskie związki między świadomością a jaźnią prowadzą do teorii świadomości, która nie nadaje się do zastosowania i działa na szkodę jego skądinąd cennego postulatu zbudowania biologicznych podstaw koncepcji jaźni.

Moje wątpliwości dotyczą zwłaszcza zaproponowanego przez Damásio podziału świadomości na świadomość rdzenną i świadomość rozszerzoną, gdzie pierwsza stanowi warunek obecności drugiej. ${ }^{1}$ Damásio wiąże świadomość rdzenną z tym, co nazywa ,jaźnią rdzenną”, najpierwotniejszą formą jaźni, którą, w celu zachowania symetrii postulowanych przezeń związków, trzeba rozważać oddzielnie i niezależnie od ,jaźni autobiograficznej”, w ramach której świadomość rozszerzona odgrywa zasadniczą rolę. ${ }^{2}$ W rzeczywistości Damásio mó-

* Gonzalo Munévar, „Damásio, Self and Consciousness”, Philosophia Scientice 2014, vol. 18, no. 3, s. 191-201, doi: 10.4000/philosophiascientiae.1015. Za zgodą Autora i Redakcji z języka angielskiego przełożył: Radosław PLATo.

${ }^{1}$ Por. António R. DAmÁsIo, Tajemnica świadomości. Jak ciało i emocje wspóltworzą świadomość, przeł. Maciej Karpiński, Nowe Horyzonty, Dom Wydawniczy REBIS, Poznań 2000, s. 91-251; António R. Damásio and Kaspar Meyer, „Consciousness: An Overview of the Phenomenon and of Its Possible Neural Basis", w: Steven Laureys and Giulio Tononi (eds.), The Neurology of Consciousness: Cognitive Neuroscience and Neuropathology, Academic Press, London 2009, s. 5 [3-14], doi: 10.1016/B978-0-12-374168-4.00001-0.

${ }^{2}$ Por. DamÁsıo, Tajemnica świadomości..., s. 110, 165; DamÁsıo and MeYer, „Consciousness...", s. 6-11. 
wi o procesie dwuetapowym: protojaźni oraz jaźni rdzennej, ${ }^{3}$ jednak przez wzgląd na zwięzłość w niniejszym eseju nie będę zajmował się tym rozróżnieniem. Będę zaś argumentował, że koncepcja „świadomości rdzennej” ma poważne wady. Koncepcja ta nie może wyjaśnić takich zjawisk jak śnienie czy zespół zamknięcia, które adekwatna teoria świadomości powinna wyjaśniać. W ramach swojej koncepcji Damásio wymaga bowiem, aby zachodzące w organizmie przetwarzanie informacji o przedmiocie wywierało wpływ na autoreprezentację organizmu. Wymogu tego nie da się spełnić w obu powyższych stanach. Co więcej, w wielu stanach, w których organizm uwzględnia efekt, powiedzmy, postrzegania przedmiotu zewnętrznego, uwzględnianie to ma charakter nieświadomy. Kolejny poważny problem polega na tym, że bliski związek między świadomością a jaźnią, jaki postuluje Damásio, prowadzi do podziału jaźni, który ze względów teoretycznych jest nie do utrzymania, ponieważ (1) ramach teorii ewolucji wymaga się, aby nawet pierwotna jaźń (to jest protojaźń) przejawiała cechy ,jaźni autobiograficznej”, oraz (2) jaźń przeważnie nie może być świadoma.

W niedawno opublikowanym artykule, trafnie zatytułowanym „Consciousness: An Overview of the Phenomenon and of Its Possible Neural Basis" [„Świadomość. Ogólny zarys zjawiska i jego możliwe neuronowe podłoże”], napisanym wraz z Kasparem Meyerem, Damásio próbuje wykazać, że jego kluczowe idee znajdują pokrycie w wynikach najnowszych badań w neuronaukach teoretycznych i eksperymentalnych. ${ }^{4}$ Skoncentruję się na tym artykule, przy okazji odnosząc się do niektórych wcześniejszych ważnych prac Damásio.

\section{Jaźń w ujęciu Damásio}

Oto krótka charakterystyka ujęcia Damásio. Do badań nad świadomością (właściwie mówi on o „definicji” świadomości) można podejść z perspektywy obserwatora, stosując zespół kryteriów behawioralnych, takich jak czuwanie,

\footnotetext{
${ }^{3}$ Por. António R. DAMÁsIO, Jak umysł zyskal jaźń. Konstruowanie świadomego mózgu, przeł. Norbert Radomski, Nowe Horyzonty, Dom Wydawniczy REBIS, Poznań 2011, s. 32-33.

${ }^{4}$ Por. DamÁsio and Meyer, „Consciousness...”.
} 
emocje tła, uwaga i zachowania celowe. ${ }^{5}$ Kluczowa jest jednak perspektywa podmiotu. Damásio skupia się przede wszystkim na wyjaśnieniu, jak, z punktu widzenia neurologii, wyłania się świadomość. Argumentuje, że z perspektywy podmiotu świadomość wyłania się, gdy mózg tworzy:

(a) neuronowe wzorce przedmiotów wyrażone w kategoriach sensomotorycznych (obrazy);

(b) neuronowe wzorce zmian, które przedmioty te wywołują w wewnętrznym stanie organizmu; oraz

(c) zapis drugiego rzędu, który wiąże ze sobą (a) i (b).

Ten zapis drugiego rzędu, opisujący relację między organizmem a przedmiotem, stanowi neuronalne podłoże subiektywności, ponieważ przedstawia organizm jako protagonistę poznającego przedmioty. W ten sposób zapis ten tworzy świadomość rdzenną. Świadomość rozszerzona zaś pojawia się, gdy przedmioty są związane z organizmem nie tylko „tu i teraz”, lecz w szerszym kontekście obejmującym ,przeszłość organizmu i jego oczekiwaną przyszłość”. Możemy więc myśleć o świadomości rdzennej jako tymczasowej („tu i teraz”), podczas gdy świadomość rozszerzona wykorzystuje zasoby pamięci roboczej oraz pamięci długotrwałej.

Przyjrzyjmy się, jak jaźń wpisuje się w ten schemat. Wytwarzanie obrazów (etap (a)) nie wystarczy do powstania świadomości. Świadomość wymaga czegoś więcej: wymaga także „utworzenia się poczucia jaźni w akcie poznawczym”. Tworzy „wiedzę o tym, że posiadamy umysł oraz że jego treści są kształtowane w szczególnej perspektywie, mianowicie w perspektywie naszego własnego organizmu”. Ponadto ,poczucie [własnego - przyp. tłum.] organizmu w akcie poznania obdarza nas poczuciem posiadania przedmiotów, które mają zostać poznane”. ${ }^{6}$ Mówi się, że organizm ludzki jest świadomy, gdy „reprezentacji przedmiotów i zdarzeń towarzyszy poczucie, że organizm jest podmiotem postrzeżeń". ${ }^{7}$ Damásio i Meyer definiują świadomość jako:

\footnotetext{
${ }^{5}$ Por. DAmÁsIo and Meyer, „Consciousness...”, s. 4.

${ }^{6}$ Damásio and Meyer, „Consciousness...”, s. 5.

${ }^{7}$ DamÁsIo and MeYer, „Consciousness...”, s. 6.
} 
[...] chwilowe utworzenie wzorców neuronowych, które opisuja związek między organizmem, z jednej strony, a przedmiotem lub zdarzeniem, z drugiej. To złożenie wzorców neuronowych opisuje stan, który, z braku lepszego słowa, nazywamy jaźnią. Ten stan jest kluczem do subiektywności. ${ }^{8}$

Tym samym świadomość rdzenna „dostarcza organizmowi poczucia jaźni w jednej chwili, teraz, i w jednym miejscu, tutaj". ${ }^{9}$ Tę ulotną jaźń, jak można było się spodziewać, Damásio określił mianem ,jaźni rdzennej” już w 1999 roku, w swojej słynnej książce Tajemnica świadomości. ${ }^{10}$ Uważni czytelnicy mogli z pewnym niepokojem zwrócić uwagę, że mieszam ze sobą jaźń i poczucie jaźni, co mogą uznać za nieuzasadnione, nawet jeśli w tym miejscu po prostu idę śladem Damásio. Mają rację, ale do tej kwestii przejdę po dalszym przedstawieniu ujęcia Damásio oraz po kilku uwagach wstępnych.

Podczas gdy świadomość rdzenna jest „prostym zjawiskiem biologicznym”, niezależnym od „pamięci konwencjonalnej, pamięci roboczej, rozumowania i języka”, świadomość rozszerzona jest złożona, uzależniona od pamięci i „poszerzana przez język”. Podobnie jaźń rdzenna stanowi „formę przejściową wiedzy”, ale to kłóci się z tradycyjnym pojęciem jaźni, które łączy się z ,ideą tożsamości i bycia osobą". To tradycyjne pojęcie, zdaniem Damásio i Meyera, odpowiada świadomości rozszerzonej: „Jaźń, która się wyłania w świadomości rozszerzonej" — powiadają — ,jest względnie stałym zbiorem niepowtarzalnych faktów, które charakteryzują osobę, jest «jaźnią autobiograficzną»". ${ }^{11}$ Oczywiście śledzenie na bieżąco tych niepowtarzalnych faktów będzie do pewnego stopnia zależeć od wspomnień z pamięci semantycznej, ale przede wszystkim od wspomnień z pamięci epizodycznej.

Zasadnicze znaczenie dla Damásio i Meyera ma to, by etapy (a)-(c) ich hipotezy o tym, jak wyłania się świadomość, wyrazić w kategoriach struktur układu nerwowego. Etap (a), tworzenie obrazów przedmiotów (w tym przywoływanie ich w pamięci), jest raczej prosty, biorąc pod uwagę wielki postęp, jaki do-

\footnotetext{
${ }^{8}$ DamÁsIo and Meyer, „Consciousness...”, s. 6 [wyróżnienie w oryginale].

${ }^{9}$ DAmÁsIO and MEYER, „Consciousness...”, s. 6.

${ }^{10}$ Por. DamÁsıo, Tajemnica świadomości....

${ }^{11}$ DamásIo and Meyer, „Consciousness...”, s. 6.
} 
konał się w neuronaukowych badaniach nad sensepcją i percepcją, nawet jeśli nadal pozostaje wiele do zrobienia. Co do etapu (b) trzeba przyznać, że Damásio sam dokonał więcej niż ktokolwiek inny w tej dziedzinie, żeby zwrócić naszą uwagę na znaczenie wyjaśniania neuronowych wzorców zmian w reprezentacji organizmu wywoływanych przez przedmioty, o których mowa w etapie (a). ${ }^{12}$ Zatem obrazy należy oceniać w kontekście reprezentacji ciała w mapach neuronowych w takich strukturach jak: pień mózgu (brainstem), podwzgórze (hypothalamus), wyspa (insular cortex), kora zakrętu obręczy (cingulate cortex) i kora ciemieniowa (parietal cortex), które pozwalają organizmowi na bieżąco śledzić „stan wewnętrznego milieu, wnętrzności, układu równowagi i układu mięśniowo-szkieletowego [...] jako zespołu aktywności, który nazywamy protojaźnią”. ${ }^{13}$ Wcześniej Damásio zdefiniował protojaźń jako:

[...] spójny zbiór wzorców neuronowych, które cyklicznie odwzorowuja stan wielu wymiarów fizycznej struktury organizmu. ${ }^{14}$

Początek świadomości przypuszczalnie charakteryzuje się „niewerbalnym zapisem”, który „opisuje związek” między „reaktywnymi” zmianami w protojaźni a ,przedmiotem wywołującym te zmiany”, to znaczy w relacji między etapami (a) i (b). Taki niewerbalny zapis ,generuje struktury zdolne do odbierania sygnałów z map, które reprezentują zarówno organizm, jak i przedmiot" ${ }^{15}$ struktury, które powinny okazać się niezbędne do powstania zarówno świadomości rdzennej, jak i rozszerzonej. Damásio przez cały czas wskazuje, że prawdopodobnie rolę tę odgrywa kora przyśrodkowa tylna (posteromedial cortex) (PMC), która stanowi „połączenie tylnego zakrętu obręczy (posterior cingulate cortex), kory retrosplenialnej (retrosplenial cortex) i przedklinka (precuneus) (pola Brodmanna $\mathrm{nr} 23 \mathrm{a} / \mathrm{b}, 29,30,31,7 \mathrm{~m}$ )". PMC pasuje idealnie, ponieważ posiada połączenia, w przeważającej mierze dwustronne, $\mathrm{z}$,prawie wszystkimi

\footnotetext{
${ }^{12}$ Por. António R. DAmÁsı, Błąd Kartezjusza. Emocje, rozum i ludzki mózg, wyd. 2. popr., przeł. Maciej Karpiński, Nowe Horyzonty, Dom Wydawniczy REBIS, Poznań 2011; DamásIo, Tajemnica świadomości....

${ }^{13}$ DamÁsIo and Meyer, „Consciousness...”, s. 8.

${ }^{14}$ DAmÁsıo, Tajemnica świadomości..., s. 165 [wyróżnienie w oryginale].

${ }^{15}$ Damásio and Meyer, „Consciousness...”, s. 8.
} 
obszarami korowymi [...] i licznymi jądrami wzgórza", ${ }^{16}$ co jest ważne, gdyż wytwarzanie wszystkich tych wzorców neuronowych „drugiego rzędu” powinno obejmować nie tylko korę, lecz także „oddziaływania wzgórzowo-korowe”. Takie bogactwo połączeń jest całkiem dogodne, bo dopuszcza udział pamięci roboczej i pamięci długotrwałej, obu niezbędnych dla rozwinięcia się jaźni autobiograficznej. Przedklinek, część PMC, uaktywnia się w trakcie „wyszukiwania zdarzeń autobiograficznych". PMC stanowi część sieci spoczynkowej, którą niektórzy badacze łączą z procesami odnoszącymi się do jaźni. W kilku badaniach techniką obrazowania mózgu okazało się, że PMC aktywowało się podczas zadań „dotyczących namysłu nad własnymi cechami osobowości osób badanych". ${ }^{17}$ Co więcej,

wszystkie przypadki upośledzenia świadomości rdzennej [...] mają pewną ważną cechę wspólną: zazwyczaj mają uszkodzony i/lub zmieniony metabolizm w licznych strukturach przyśrodkowych, takich jak PMC. ${ }^{18}$

Należy też wspomnieć, że PMC bynajmniej nie jest pierwszym wyborem większości neuronaukowców badających jaźń. Wielu wyraźnie preferuje, na przykład, przyśrodkową korę przedczołową (medial prefrontal cortex), powołując się również na bogactwo połączeń korowych i wzgórzowych, bezpośredni udział pamięci roboczej i wiele innych czynników. ${ }^{19}$ Mimo to Damásio i Meyer mogą uznać PMC za część większej sieci struktur przyśrodkowych.

\section{Krytyka ujęcia Damásio}

Zacznę od wskazania na niejednoznaczność rezultatów badań techniką obrazowania mózgu uzyskiwanych, jak w cytowanych powyżej sprawozdaniach o pobudzeniu PMC (lub innych struktur), w zadaniach „dotyczących namysłu

\footnotetext{
${ }^{16}$ DamÁsIo and Meyer, „Consciousness...”, s. 9.

${ }^{17}$ DamÁsIo and MeYer, „Consciousness...”, s. 9.

${ }^{18}$ Damásio and Meyer, „Consciousness...”, s. 10.

${ }^{19}$ Por. C. Neil Macrae, Todd F. Heatherton, and William M. Kelley, „A Self Less Ordinary: The Medial Prefrontal Cortex and You”, w: Michael S. Gazzaniga (ed.), The Cognitive Neurosciences III, A Bradford Book, MIT Press, Cambridge, Massachusetts — London 2004, s. 1067-
} 1075 . 
nad własnymi cechami osobowości osób badanych". Takie zadania prawie zawsze są wykonywane względem lub $\mathrm{w}$ zestawieniu $\mathrm{z}$ innymi zadaniami. Jako przykład rozważmy badanie fMRI dotyczące autoatrybucji, jakie przeprowadziłem z moim współpracownikiem Matthew Colem w Laboratorium Rezonansu Magnetycznego Marka Haacke'a w Harper's Hospital na Wayne State University. Prosiliśmy osoby badane, żeby odpowiadały na pytania o cechy osobowości odnoszące się do nich samych i ich najlepszych przyjaciół (na przykład „Czy jesteś życzliwy?”, „Czy twój najlepszy przyjaciel jest życzliwy?”). W innych warunkach pytaliśmy także, czy przypisaliby sobie lub swoim najlepszym przyjaciołom różne cechy nieosobowościowe (na przykład „Czy jesteś wysoki?”, „Czy twój najlepszy przyjaciel jest wysoki?"). Zestawienie ze sobą połączonych warunków pytań o siebie z połączonymi warunkami pytań o najlepszego przyjaciela, jak widać na Rys. 1, ujawniło, że w tym konkretnym zestawieniu autoatrybucji towarzyszyła wyraźna różnica w pobudzeniu pola Brodmanna nr 31, stanowiącego część PMC. Wobec tego na pierwszy rzut oka wydaje się, że wyniki moich własnych badań eksperymentalnych wspierają teoretyczny argument Damásio.

Tymczasem, gdy zestawiliśmy pytania o siebie z pytaniami o sławną osobę, której uczestnicy nie znają osobiście (Billa Gatesa), rezultaty były zupełnie inne. Okazało się mianowicie, że zupełnie inny obszar, przedni zakręt kory obręczy (anterior cingulate cortex) (AAC), wykazywał największą różnicę pobudzenia, jak widać na Rys. 2. Rezultat ten, uzyskany u dokładnie tych samych uczestników w trakcie dokładnie tych samych sesji w skanerze fMRI, nie wydaje się już wspierać teoretycznego argumentu Damásio (ACC nie stanowi części PMC).

W trakcie porównywania połączonych warunków pytań o najlepszego przyjaciela i Billa Gatesa trudności przybywa, chyba że przyjmiemy inne podejście. Jak widzimy na Rys. 3, wzorzec pobudzenia jest praktycznie taki sam, jak w porównaniu warunków pytań o siebie i Billa Gatesa, chociaż poziom pobudzenia jest niższy. 

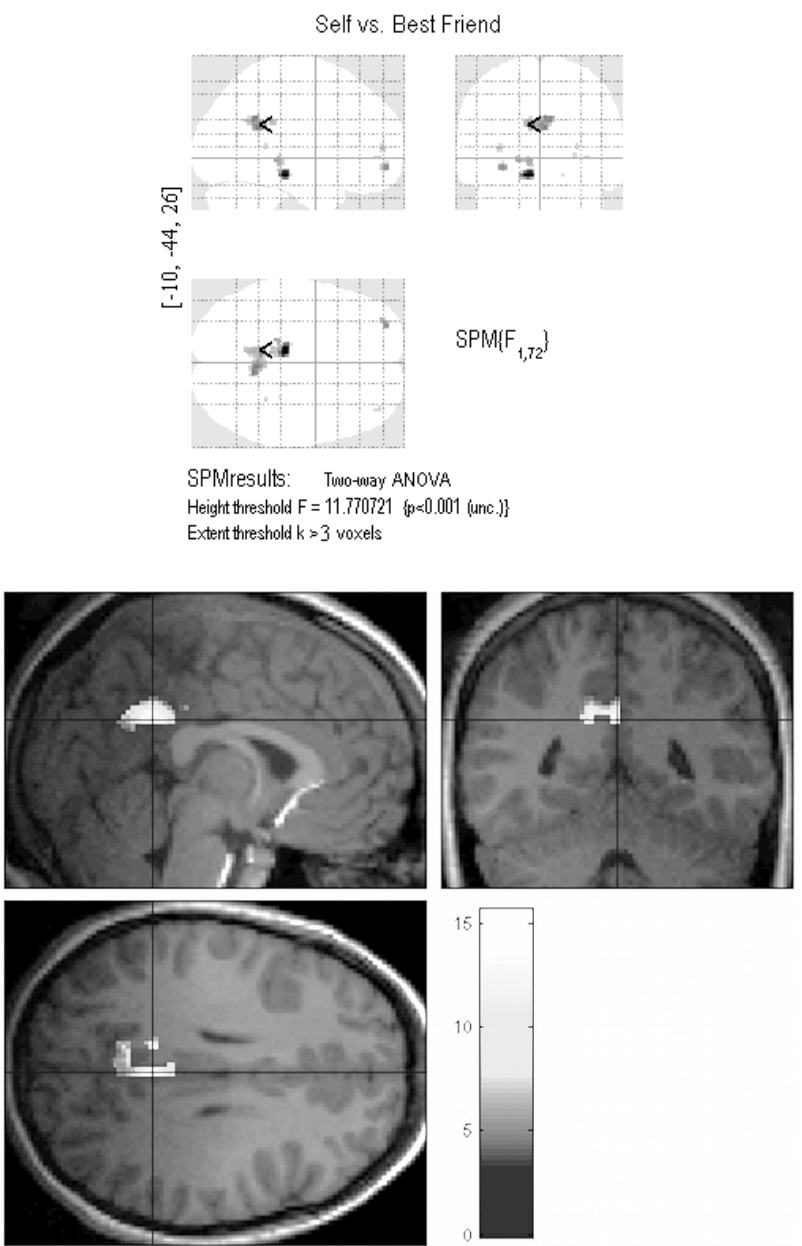

Rys. 1. Znaczące pobudzenie płata limbicznego (limbic lobe) i zakrętu obręczy (cingulate gyrus) w polu Brodmanna nr 31 (ja sam-najlepszy przyjaciel). Uśrednione złożenie obrazu 13 uczestników. Badanie fMRI neuronalnych korelatów jaźni. ${ }^{20}$

\footnotetext{
${ }^{20}$ Por. Gonzalo Munévar, Matthew L. Cole, Yongquan Ye, Jie Yang, Yi Zheng, Uday KrishNAmURThy, and Mark HaAcKe, „fMRI Study of Self vs. Others' Attributions of Traits Consistent with Evolutionary Understanding of the Self", Neuroscience Discovery 2014, vol. 2, no. 3, s. 1-7, doi: $10.7243 / 2052-6946-2-3$.
} 

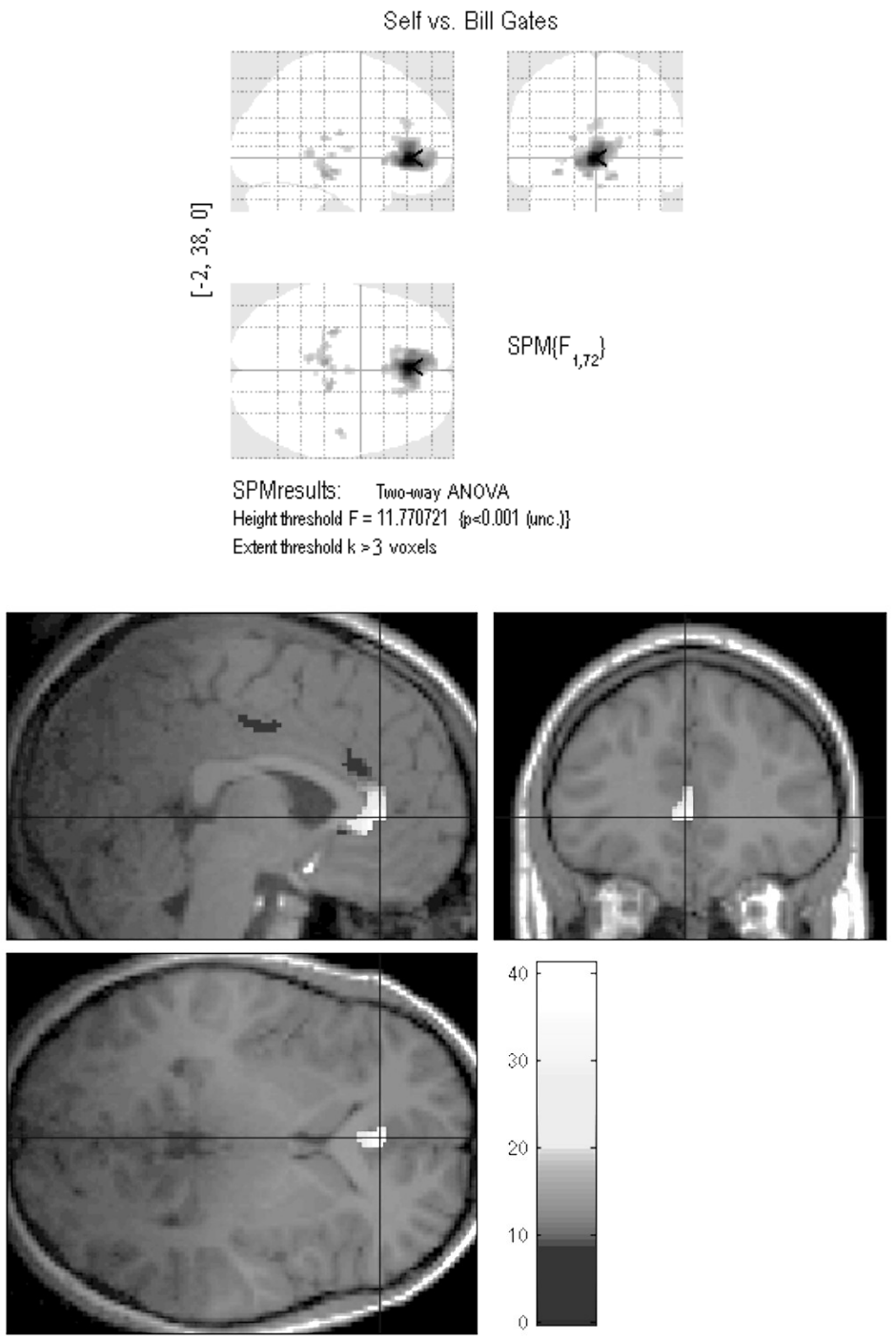

Rys. 2. Pobudzenie ACC w zadaniu polegającym na autoatrybucji, ja sam-Bill Gates, badanie fMRI. ${ }^{21}$

${ }^{21}$ Por. Munévar, Cole, Ye, Yang, Zheng, Krishnamurthy, and Haacke, „fMri Study of Self...". 

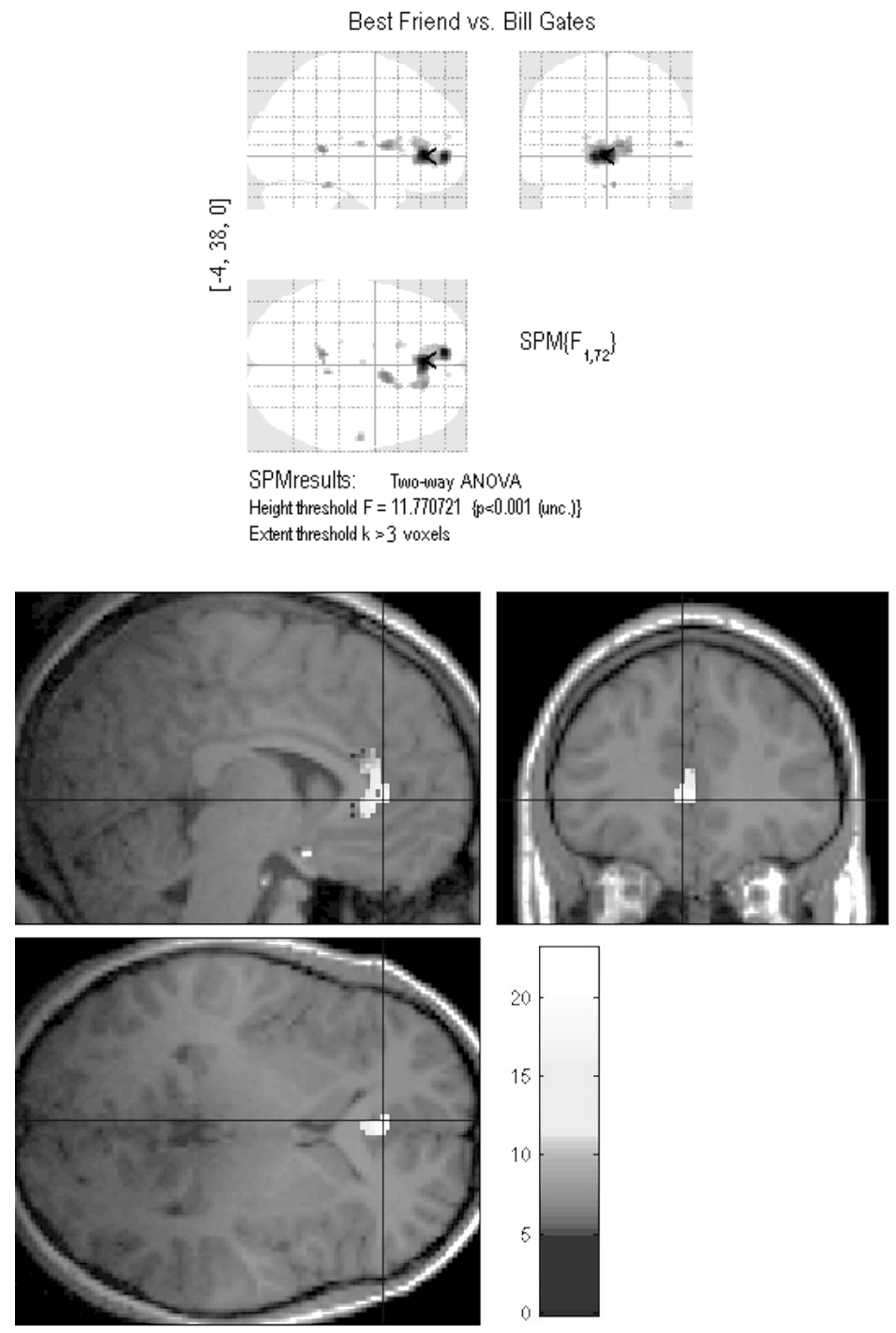

Rys. 3. Pobudzenie ACC podczas zestawienia najlepszy przyjaciel-Bill Gates. ${ }^{22}$

${ }^{22}$ Por. Munévar, Cole, Ye, Yang, Zheng, Krishnamurthy, and Haacke, „fMri Study of Self...". 
Sprawa staje się jeszcze bardziej skomplikowana, gdy zmieniamy charakter zadania. To znaczy, gdy przeprowadzamy eksperyment polegający na rozpoznawaniu siebie zamiast na przypisywaniu sobie cech — na przykład prosząc osoby badane o zidentyfikowanie fotografii przedstawiających ich samych w przeciwieństwie do fotografii ich najlepszych przyjaciół czy nieznajomych — to znacząco pobudzone zostają zupełnie inne obszary mózgu. ${ }^{23}$ To mnożenie wielorakich rezultatów może doprowadzić do rozpaczy niektórych obserwatorów dziedziny neuronaukowych badań nad jaźnią. ${ }^{24}$ Wydaje się, że możliwych jest wiele rodzajów odróżniania siebie od innych, a także wiele sposobów, na jakie mózg może przeprowadzać takie odróżnienia. Jak zwięźle omówię poniżej, ta sytuacja jest jednak całkowicie zgodna $\mathrm{z}$ wyjaśnieniem jaźni wynikającym $\mathrm{z}$ teorii ewolucji, mianowicie takim, które, w przeciwieństwie do rozwiązania Damásio, nie podporządkowuje jaźni świadomości.

Zanim jednak przejdziemy do dalszej dyskusji, należy zdać sobie sprawę, że między ujęciem Damásio a pewnymi ważnymi ustaleniami neuronauk zachodzą także inne niezgodności. Po pierwsze, ze względu na to, że postulowana przez Damásio jaźń autobiograficzna zależy od wspomnień epizodycznych dotyczących przeżyć podmiotu, jest mało prawdopodobne, by była czymś więcej niż konstrukcją myślową. Jak jasno wykazał Stanley Klein na podstawie studiów przypadku, jaźń nie może być konstytuowana przez wspomnienia epizodyczne z bardzo prostego powodu: pacjenci całkowicie niezdolni do kształtowania wspomnień epizodycznych (ponieważ nie posiadają już hipokampu) mimo to są w stanie rzetelnie opisać swoje cechy osobowości. ${ }^{25}$ Pacjenci przejawiający poważne zmiany osobowości po doznaniu urazu nadal byli w stanie opisać swoje

\footnotetext{
${ }^{23}$ Por. Steven M. Platek, James W. Loughead, Ruben C. Gur, Samantha Busch, Kosha RupaRel, Nicholas Phend, Ivan S. PAnyavin, and Daniel D. Langleben, „Neural Substrates for Functionally Discriminating Self-Face from Personally Familiar Faces”, Human Brain Mapping 2006, vol. 27, no. 2, s. 91-98, doi: 10.1002/hbm.20168.

${ }^{24}$ Por. Georg Northoff, Alexander Heinzel, Moritz de Greck, Felix Bermpohl, Henrik Dobrowolny, and Jaak PANKSEPP, ,Self-Referential Processing in Our Brain - A Meta-Analysis of Imaging Studies on the Self", NeuroImage 2006, vol. 31, no. 1, s. 440-457, doi: 10.1016/j.neuroim age.2005.12.002.

${ }^{25}$ Por. Stanley B. Klein, „The Cognitive Neuroscience of Knowing One's Self”, w: GazzanIGA (ed.), The Cognitive Neurosciences III..., s. 1077-1089.
} 
nowe cechy osobowości mimo utraty zdolności kształtowania wspomnień epizodycznych.

Po drugie, co wiąże się z tematem konstrukcji myślowych, wydaje się dziwne, że autor Błędu Kartezjusza powinien usiłować podporządkowywać jaźń świadomości. ${ }^{26}$ To kartezjańskie zaangażowanie wypływa $\mathrm{z}$ celu przyświecającego Damásio, jakim jest wyjaśnienie pojęcia subiektywności, a zwłaszcza ustalenie, dlaczego rzeczywiście odczuwamy nasze przeżycia jako „nasze”. Jednak zwrócenie uwagi na tę sprawę, nawet na poziomie fenomenologii, pokazuje, że w trakcie intensywnych przeżyć percepcyjnych (na przykład słuchania muzyki, którą uważamy za naprawdę piękną) możemy wejść w stan, w którym nie myślimy o sobie. Francis Crick i Christof Koch poradzili sobie z tym kontrświadectwem dzięki sugestii, że mózg wciąż oznakowuje wszystkie przeżycia, chociaż w takich wypadkach robi to podświadomie, najprawdopodobniej przez aktywację obszarów czołowych (nawet gdyby preferowana przez Damásio PMC stanowiła kluczowy rejon, to musiałaby działać poprzez obszary czołowe, zważywszy na brak połączeń PMC z pierwszorzędowymi obszarami sensorycznymi i motorycznymi). ${ }^{27}$ Ale niedawny eksperyment pokazał, że w trakcie intensywnych zadań percepcyjnych pobudzenie płata czołowego w rzeczywistości słabnie! ${ }^{28}$

Co więcej, mieszając jaźń z poczuciem jaźni, jak wspomniano wcześniej, Damásio wywołuje poważne wątpliwości co do istnienia jaźni. W ramach jego ujęcia można, jak się wydaje, uczciwie przyjąć, że jaźń stanowi odpowiednik percepcji wewnętrznej. Rodolfo Llinás na pewno zinterpretował tę sprawę w ten sposób. Ale jeśli tak jest, konkluduje Llinás, to jaźń jest iluzją! ${ }^{29}$ Inni natomiast

\footnotetext{
${ }^{26}$ Por. DAmÁsıo, Błąd Kartezjusza....

${ }^{27}$ Por. Francis CRICK i Christof KocH, „Rama teoretyczna dla świadomości”, przeł. Anna Binder i Marek Binder, w: Andrzej KLAwITER (red.), Formy aktywności umysłu. Ujęcia kognitywistyczne. Tom 1. Emocje, percepcja, świadomość, Nowe Tendencje w Psychologii, t. 13, Wydawnictwo Naukowe PWN, Warszawa 2008, s. 302-323.

${ }^{28}$ Por. Ilan I. Goldberg, Michal Harel, and Rafael Malach, „When the Brain Loses Its Self: Prefrontal Inactivation during Sensorimotor Processing”, Neuron 2006, vol. 50, no. 2, s. 329-339, doi: 10.1016/j.neuron.2006.03.015.

${ }^{29}$ Por. Rodolfo R. Llinás, Ja z wiru. Od neuronów do selfu, przeł. Jan J. Trąbka i Piotr K. Walecki, b.w., Kraków 2008.
} 
wolą mówić o konstrukcji, nadal, że tak powiem, pozostawiając w zawieszeniu status ontyczny jaźni. Zresztą jeśli naprawdę posiadamy jaźń, to bez względu na to, czym jest, powinna się ona ontycznie różnić od naszej wewnętrznej percepcji jaźni, tak jak słoń z pewnością różni się ontycznie od naszej percepcji słonia.

W każdym razie nacisk, jaki Damásio kładzie na świadomą jaźń, prowadzi do innych problemów. Na przykład koncepcja świadomej jaźni jako czynnika podejmującego decyzje koliduje z wynikami eksperymentów, takich jak eksperyment Libeta, w którym zostało wykazane, że podczas zaciskania dłoni nieświadomy potencjał gotowości mózgu pojawia się przeciętnie 350 milisekund przed tym, zanim osoba badana ma świadomą myśl o poruszeniu dłonią. ${ }^{30}$

Oprócz tego skutki, jakie percepcja wywiera na organizm, nawet gdy wszystkie wymogi stawiane przez Damásio świadomości rdzennej zostaną spełnione, normalnie są realizowane nieświadomie. Spotykamy jakąś osobę i prawie natychmiast niewerbalne ,przetwarzanie” informacji zależy od bardzo wielu wskazówek, które same zależą od nieświadomych procesów opartych na racjach ewolucyjnych lub na długiej historii osobistych przeżyć. Ta nowa osoba wygląda na godną zaufania, interesującą i tak dalej, ale często nie mamy pojęcia, dlaczego rzeczywiste świadome przeżycie jest związane z tymi reakcjami, a nawet możemy nie być świadomi samych tych reakcji. Istotnie, jak wskazał Crick, większość funkcji mózgu, w tym funkcji poznawczych, jest nieświadoma. Powinniśmy zatem oczekiwać, że jaźń, jeśli istnieje, przeważnie ma charakter nieświadomy. Gdy zignorujemy tę kwestię, myśląc, że jaźń jest świadoma (lub gorzej, kartezjańska), to, jak widzieliśmy, powstają najprzeróżniejsze paradoksy.

We wcześniejszych pracach zaproponowałem, byśmy myśleli o jaźni w kontekście biologii ewolucyjnej. ${ }^{31}$ Każdy organizm musi odgraniczać siebie od in-

(Przyp. tłum.) W lepszym przekładzie na język polski ukazał się także rozdział 6 (s. 111-131) wspomnianej pracy w postaci artykułu pt. „Ja z wiru”. Por. Rodolfo R. Llinás, „Ja z wiru”, przeł. Anna Binder i Marek Binder, w: KLAwITER (red.), Formy aktywności umysłu..., s. 364-384.

${ }^{30}$ Por. Benjamin LiвET, „Unconscious Cerebral Initiative and the Role of Conscious Will in Voluntary Action”, The Behavioral and Brain Sciences 1985, vol. 8, no. 4, s. 529-539, doi: 10.10 17/S0140525X00044903.

${ }^{31}$ Por. Gonzalo MunÉvar, „Naturalistyczne wyjaśnienie wolnej woli (II)”, przeł. Radosław Plato, Filozoficzne Aspekty Genezy 2014, t. 11, s. 161-184, http:/www.nauka-a-religia.uz.zgora. pl/images/FAG/2014.t.11/art.07.pdf (16.08.2015); Gonzalo MunÉvAR, „A Darwinian Account of 
nych, lecz w przypadku bardziej złożonych organizmów, takich jak ssaki, spełnienie tej potrzeby wykracza poza reakcje układu odpornościowego, wymaga bowiem koordynacji informacji zewnętrznej z informacją dotyczącą wewnętrznych stanów organizmu. Aby taka koordynacja była skuteczna, musi uwzględniać wcześniejsze przeżycia organizmu, jak również jego dziedzictwo genetyczne, na przykład w postaci podstawowych emocji, które kierują nim, by przetrwał, rozmnożył się i tak dalej, jak sam Damásio tak umiejętnie argumentował. A przeżycia, jak wskazywał, muszą być interpretowane na podstawie tego, za kogo organizm siebie „uważa”, lecz, ponownie, jest to przeważnie podświadome zadanie przypisane głównie ośrodkowemu układowi nerwowemu, a zwłaszcza mózgowi.

Mózg, któremu nie udaje się dostrzec związków niezbędnych do wykonania takiej koordynacji i interpretacji, stawia organizm w niekorzystnej sytuacji. Może na przykład mieć trudności w uczeniu się i zapamiętywaniu zasadniczych faktów dotyczących swego środowiska lub nie być w stanie ujednoznaczniać informacji percepcyjnej o kluczowym znaczeniu. Układ limbiczny szczura, głównie ciało migdałowate (amygdala) i wyspa, powstrzymuje go od zjadania pożywienia, które wcześniej mu zaszkodziło. Jest to proces nieświadomy, który ma odpowiedniki także u istot ludzkich.

Mózg, który wyewoluował, żeby łączyć ze sobą informację zewnętrzną i wewnętrzną w kontekście swojej własnej historii (lub raczej swojej reprezentacji tej historii) oraz aby odróżniać swój organizm od innych, to mózg, który wyewoluował do pełnienia funkcji zazwyczaj przypisywanych jaźni: bycie jaźnią jest w znacznym stopniu tym, co robi mózg. Lecz mózg przeważnie robi to nieświadomie (lub podświadomie). Biorąc pod uwagę, że mózg jest systemem rozproszonym oraz że istnieją miriady sposobów, w jakie osobnik musi odróżniać siebie od innych, wydaje się, że jaźń prawdopodobnie także ma charakter rozproszony. To wyjaśniałoby, dlaczego różne zadania dotyczące ,jaźni” dają w różnorodnych eksperymentach $\mathrm{z}$ obrazowaniem mózgu tak rozmaite wzorce aktywacji mózgu. A ponieważ jesteśmy zwierzętami społecznymi, to ewolucyj-

Self and Free Will", w: Martin Brinkworth and Friedel Weinert (eds.), Evolution 2.0: Implications of Darwinism in Philosophy and the Social and Natural Sciences, The Frontiers Collection, Springer-Verlag, Heidelberg — Dordrecht — London - New York 2012, s. 43-63, doi: 10. 1007/978-3-642-20496-8_5 (przekład polski w przygotowaniu). 
ne ujęcie wyjaśnia także, dlaczego w eksperymencie dotyczącym autoatrybucji, przywołanym tu dla przykładu, oba zestawienia: ja sam-Bill Gates i najlepszy przyjaciel-Bill Gates pobudziły ACC (chociaż z różną intensywnością). Mamy skłonność do identyfikowania się z tymi, którzy są nam bliscy. Co do aktywacji pola Brodmanna $\mathrm{nr} 31 \mathrm{w}$ zestawieniu ja sam-Bill Gates: jest to obszar, który stanowi podstawę orientacji przestrzennej organizmu ze względu na „obiektywne” cechy, takie jak punkty orientacyjne, ${ }^{32} \mathrm{w}$ przeciwieństwie do orientacji egocentrycznej (gdzie sugestia dotyczy „uprzedmiotowienia” rozróżnienia między organizmem a tym, co jest mu bliskie). Orientacja ma zasadnicze znaczenie dla organizmów, które wyewoluowały do działania. Nawiasem mówiąc, pobudzenie ACC pokazane na Rys. 2 i 3 samo daje swoistą biologiczną premię: obszar ten jest anatomicznie zmniejszony u schizofreników, którzy notorycznie mają trudności z odróżnianiem siebie od innych. ${ }^{33}$

Oczywiście kwestia świadomości pozostanie niezwykle doniosła, a wyjaśnienie Damásio, skorygowane tak, aby wyjaśnić jedynie, jak świadomość może powstać $\mathrm{w}$ wyniku pewnych zmian protojaźni wywoływanych przez przedmioty, nadal może być owocne. Jednak niektóre zagadki pozostają. Na przykład w typowych snach w fazie REM, w odróżnieniu od typowych percepcji wzrokowych, ciało nie reaguje zbytnio na treść przeżycia snu, ponieważ obszary wzgórzowo-korowe zostają w znacznym stopniu funkcjonalnie „odłączone” od reszty mózgu, a w niewielkim stopniu dzieje się tak dlatego, że taka treść nie wpływa na autoreprezentację ciała $w$ sposób świadomy. Aby tak było, musielibyśmy być świadomi, że śnimy, a na ogół nie jesteśmy. Czasami niektóre jednostki są świadome, że śnią. Takie przypadki stanowią przykłady ,świadomych snów”. Ale większość ludzi przeważnie nie ma świadomych snów.

W przypadku zespołu zamknięcia pacjent jest świadomy, mimo że jest całkowicie sparaliżowany. Wymogi Damásio dla świadomości rdzennej nie tylko

\footnotetext{
${ }^{32}$ Por. Oliver Baumann and Jason B. Mattingley, „Medial Parietal Cortex Encodes Perceived Heading Direction in Humans", The Journal of Neuroscience 2010, vol. 30, no. 39, s. 1289712901, doi: 10.1523/JNEUROSCI.3077-10.2010.

${ }^{33}$ Por. Alex Fornito, Murat Yücel, Brian Dean, Stephen J. Wood, and Christos Pantelis, „Anatomical Abnormalities of the Anterior Cingulate Cortex in Schizophrenia: Bridging the Gap Between Neuroimaging and Neuropathology", Schizophrenia Bulletin 2009, vol. 35 no. 5, s. 973 993, doi: 10.1093/schbul/sbn025.
} 
nie są spełnione, chociaż pacjent powinien posiadać przynajmniej świadomość rdzenną, ale zespół ten jest powodowany przez uszkodzenie mostu (pons), jednej spośród właśnie tych struktur w mózgu, które Damásio uznaje za niezbędne dla świadomości rdzennej.

Nic z tego, co zostało powiedziane wyżej, nie miało sugerować, że świadomość nie odgrywa żadnej roli w naszym życiu mentalnym czy wręcz w kształtowaniu naszego poczucia jaźni. Jednak wciąż należy wyjaśnić, na czym ta rola może polegać. Pewną interesującą hipotezą, już wspomnianą, jest potraktowanie świadomości jako zjawiska pokrewnego percepcji wewnętrznej, a czasami wewnętrznej percepcji jaźni, miewającej swoje wybryki i podatnej na złudzenia tak samo, jak wszystkie inne percepcje. Tak czy owak wygląda na to, że narzucanie jaźni własności, jaką jest świadomość, czego próbuje Damásio, kończy się niepowodzeniem, a to rzuca cień na skądinąd ważne ustalenia dotyczące umysłu, jakich dokonat.

Gonzalo Munévar

\section{Damásio, Self and Consciousness}

\section{Summary}

António Damásio's notion of "core consciousness" suffers from serious defects. It cannot account for phenomena such as dreaming or locked-in-syndrome, which a proper theory of consciousness should explain, because it requires that the organism's self-representation be affected by the organism's processing of an object. This requirement cannot be met in those two states. Moreover, in many states in which the organism does take into account the effect of, say, the perception of an external object, that account is unconscious. And lastly, the close connection Damásio makes between consciousness and the self leads to a theoretically untenable division of the self: evolutionary considerations demand that even a primitive self (e.g., a proto-self) exhibit features of an "autobiographical self".

Keywords: consciousness, self, distributive self, neuroscience, brain-imaging, António Damásio.

Słowa kluczowe: świadomość, jaźń, jaźń rozproszona, neuronauka, obrazowanie mózgu, António Damásio. 